\title{
PENGGUNAAN Lemna sp SEBAGAI PAKAN DALAM BUDIDAYA IKAN GURAME (OSPHRONEMUS GOURAMI LAC.) DI KABUPATEN PANGANDARAN
}

\author{
Yuli Andriani, Iskandar dan Irfan Zidni \\ Prodi Perikanan, Fakultas Perikanan dan Ilmu Kelautan Universitas Padjadjaran \\ Jln. Raya Bandung Sumedang KM 21, Jatinangor 40600 \\ E-mail'1:yuli.andriani@unpad.ac.id
}

\begin{abstract}
ABSTRAK. Ikan gurame (Osphronemus gouramy Lac.) merupakan jenis ikan unggulan Jawa Barat yang memiliki nilai ekonomis tinggi. Salah satu kelompok yang melakukan pembudidayaan ikan gurame adalah Kelompok pembudidaya ikan gurame Kawungsari di Desa Kertayasa Kecamatan Cijulang Kabupaten Pangandaran. Selain sebagai mata pencaharian melalui budidaya ikan secara umum, kelompok ini bermaksud mengembangkan ikan gurame sebagai komoditas unggulan daerah. Salah satu alternatif penyediaan pakan hijauan untuk ikan gurame adalah Lemna sp. Lemna sp adalah tanaman air yang berukuran kecil yang mengapung di atas air dan berpotensi sebagai pakan segar ataupun bahan pakan karena memiliki kandungan nutrisi yang cukup tinggi. Kandungan protein berkisar 10-45 \%, serat 7-14\%, karbohidrat 35\%, lemak 3-7\%, dan kandungan vitamin dan mineral yang cukup tinggi. Tanaman air ini memiliki produktivitas yang tinggi. Dalam kondisi optimal jenis tumbuhan ini dapat menggandakan biomassanya hanya dalam waktu dua hari. Produksi Lemna sp. dapat mencapai hingga 30 ton berat kering/ha. Tujuan kegiatan ini adalah untuk meningkatkan pengetahuan dan keterampilam para petani ikan tentang cara membudidayakan Lemna sp sebagai sumber pakan hijauan sehingga diharapkan dan meningkatkan produksi ikan gurame di Kelompok pembudidaya ikan gurame Kawungsari di Desa Kertayasa Kecamatan Cijulang Kabupaten Pangandaran. Hasil dari kegiatan pengabdian kepada masyarakat adalah meningkatnya produksi lemna oleh pembudidaya ikan gurame sebagai pakan ikan.
\end{abstract}

Kata kunci: Gurame, Lemna, Pakan hijauan

\section{THE USE OF Lemna Sp AS FEED IN GURAME (OSPHRONEMUS GOURAMI LAC.) CULTURE IN PANGANDARAN REGENCY}

\begin{abstract}
Gouramy (Osphronemus gouramy Lac.) is a famous fish of West Java, which has a high economic value. One group that cultivation carp is a group of Kawungsari carp breeders in Kertayasa Village, Cijulang District, Pangandaran Regency. Besides as a livelihood through fish farming in general, this group intends to develop carp as the region's superior commodities. One of the alternative feed provision for gouramy fish is Lemna sp. Lemna sp is a small aquatic plant that floats on water and has potential as a fresh feed or feed ingredients because it has a sufficient nutrient content. Protein content ranges from 10-45\%, 7-14\% fiber, 35\% carbohydrate, 3-7\% fat, and high enough vitamin and mineral content. This water plant has high productivity. Under optimal conditions this plant species can double its biomass in just two days. The production of Lemna sp. can reach up to 30 tons dry weight / ha. The purpose of this activity is to improve the knowledge and skills of the fish farmers on how to grow Lemna sp as a source of forage feed so it is expected and increase the production of carp in Kawungsari Gouramy farmer group in Kertayasa Village, Cijulang District, Pangandaran Regency. The result from this activity has successfully increase the productivity of lemna for fish feed of Gouramy.
\end{abstract}

Key words: Feed provision, Gouramy, Lemna

\section{PENDAHULUAN}

Ikan Gurame (Osphronemus gouramy Lac.) adalah salah satu komoditas perikanan yang potensial untuk dikembangkan dan memiliki nilai ekonomis yang tinggi. Salah satu kelompok yang melakukan pembudidayaan ikan gurame adalah kelompok pembudidaya ikan gurame Kawungsari di Desa Kertayasa Kecamatan Cijulang Kabupaten Pangandaran. Selain sebagai mata pencaharian melalui budidaya ikan secara umum, kelompok ini bermaksud mengembangkan ikan gurame sebagai komoditas unggulan daerah.

Keberhasilan budidaya ikan gurame ditentukan salah satunya oleh ketersediaan pakan yang bersumber dari hijauan. Ikan gurame merupakan ikan omnivora yang cenderung herbivora yang memiliki kebiasaan mengkonsumsi hijauan seperti daun sente (Alocasia Macrorrhiza Schott). Simbiosis ikan gurame dan daun sente sebagai pakannya akan terkendala pada penyediaan daun sente yang semakin terbatas. Berdasarkan hal itu perlu dilakukan diversifikasi hijauan yang potensial untuk mensubstitusi kebutuhan hijauan dari daun sente dalam budidaya ikan gurame.

Salah satu alternatif penyediaan pakan hijauan untuk ikan gurame adalah Lemna sp. Lemna sp adalah tanaman air yang berukuran kecil yang mengapung di atas air dan berpotensi sebagai pakan segar ataupun bahan pakan karena memiliki kandungan nutrisi yang cukup tinggi. Kandungan protein berkisar 10-45\% (Landesman et al. 2005, Iqbal 1999), serat 7-14\%, karbohidrat 35\%, lemak 3-7\%, dan kandungan vitamin dan mineral yang cukup tinggi (Iqbal 1999). Tanaman air ini memiliki produktivitas yang tinggi. Dalam kondisi optimal jenis tumbuhan ini dapat menggandakan biomassanya hanya dalam waktu dua hari (Landesman et al. 2005). Leng et al. (1995) menyatakan produksi 
Lemna sp. dapat mencapai hingga 30 ton berat kering/ ha.

Penelitian penggunaan Lemna sp. sebagai pakan ikan menunjukkan hasil yang memuaskan. Penelitian Nekoubin dan Sudagar (2013) menunjukkan pemberian $20 \%$ Lemna sp. segar pada ikan grass carp menghasilkan laju pertumbuhan spesifik 0,55\% yang lebih besar dibandingkan dengan kontrol hanya 0,33\%. Sulawesty dkk. (2014) bahwa pakan pelet 1,5\% bobot ikan dan L. perpusilla segar setara dengan berat keringnya sebanyak 1,5\% bobot ikan dapat menghasilkan laju pertumbuhan spesifik ikan mas (Cyprinus carpio L)

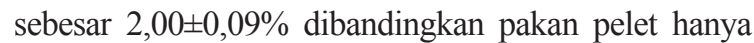
$1,75 \pm 0,03 \%$. Penelitian kombinasi $75 \%$ pelet $+25 \%$ L. perpusilla segar pada ikan nila menghasilkan pertumbuhan bobot mutlak 30,95 gram yang tidak berbeda nyata dengan pemberian pakan pelet $100 \%$ (Ilyas dkk. 2014). Hal ini menunjukkan bahwa Lemna sp. sangat berpotensi sebagai pakan alternatif. Dengan pemberian informasi tentang cara budidaya Lemna $\mathrm{sp}$ dan cara pemberiannya sebagai pakan ikan gurame kepada para petani, maka diharapkan upaya perbaikan kinerja produksi ikan gurame dapat dioptimalkan dengan baik.

\section{METODE}

Metode yang akan digunakan dalam penyampaian informasi dalam kegiatan ini adalah: :

a. Penyuluhan, dalam kegiatan ini akan diberikan materi teoritis dan penyampaian informasi mengenai pentingnya nutrisi yang berasal dari pakan hijauan Lemna sp untuk benih ikan, khususnya ikan gurame.

b. Demonstrasi plot cara budidaya Lemna sp, kegiatan ini berisi tentang praktek atau demonstrasi cara membiakkan Lemna sp menggunakan pupuk bioslurry dari peternakan sapi.

c. Diskusi, kegiatan ini menampung seluruh pertanyaan dan saran serta bertukar pikiran dalam hal budidaya umumnya, khususnya tentang budidaya pakan alami.

1. Metode dalam pelaksanaan monitoring akan dilakukan secara berkala dengan kunjungan lapangan setiap bulan dan melalui telepon. Cakupan monitoring meliputi pemantauan produksi budidaya Lemna sp dan respon ikan terhadap pakan yang diberikan. Alat dan bahan yang digunakan adalah bibit Lemna sp dan bioslurry (limbah sisa biogas kotoran sapi).

2. Metode evalusi akan dilaksanakan akhir kegiatan melalui pemberian kuesioner kepada para pembudidaya ikan gurame di Kertayasa. Hasi evaluasi dapat mencerminkan seberapa banyak informasi dan pemahaman yang dapat diserap oleh para peserta kegiatan. Keberhasilan penerapan program juga dievaluasi melalui tingkat kehadiran peserta selama kegiatan berlangsung.

\section{HASIL DAN PEMBAHASAN \\ Kegiatan Penyuluhan}

Kegiatan penyuluhan dilaksanakan di kediaman ketua kelompok tani Kawungsari, Pak Cholil, dan dihadiri oleh para anggota kelompok dan aparat dari Dinas Perikanan dan Kelautan Cijulang Ciamis. Pada kata sambutannya, pihak dinas mengungkapkan aprsiasi dan harapan untuk pengembangan kerjasama kemitraan yang berlanjut dengan Fakultas Perikanan dan Ilmu Kelautan Unpad dalam pengembangan kegiatan budi daya perikanan di Cijulang Ciamis.

Respon peserta dalam mengikuti kegiatan penyuluhan sangat baik. Hal ini terlihat dari tingkat kehadiran yang tinggi serta antusiasme para peserta kegiatan mengikuti sesi pemaparan dan diskusi. Kehadiran peserta penyuluhan terdiri dari 20 orang dari target 25 orang pembudidaya ikan gurame. Pertanyaan-pertanyaan yang dilontarkan peserta berkisar di seputar budidaya gurame dan kendala yang dihadapi. Termasuk salah satu masalah yang dihadapi oleh kelompok tani ini adalah masalah induk yang berkualitas, serangan hama dan penyakit, serta pakan. Dalam kesempatan ini kami dari FPIK Unpad mencoba memberikan solusi dan informasi yang relevan sehingga diskusi menjadi bernas dan bermanfaat.

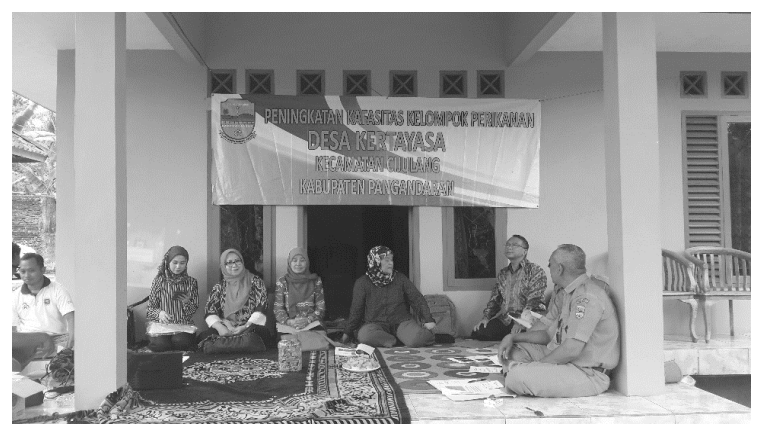

Gambar 1. Tim FPIK Unpad dan aparat desa di tempat penyuluhan

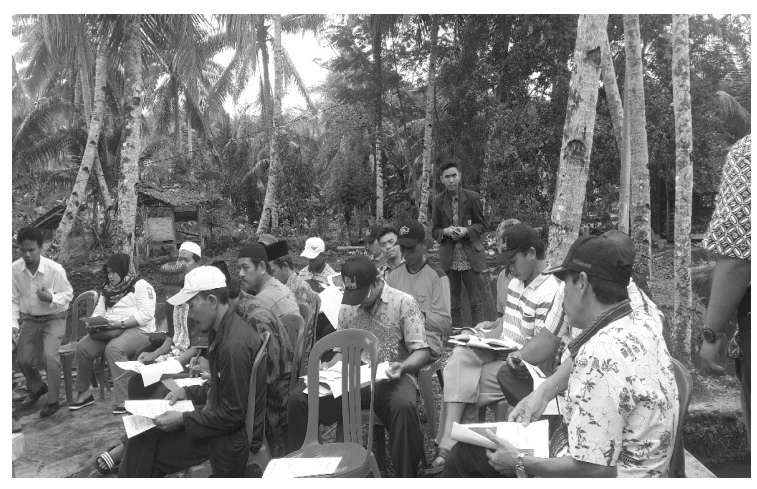

Gambar 2. Peserta kegiatan sedang menyimak materi penyuluhan

Materi pelatihan yang disampaikan mencakup tentang pakan hijauan bagi ikan herbivora dan berbagai contohnya, termasuk Lemna sp. Pada diskusi terungkap bahwa Lemna sp tidak terdapat di perairan sekitar lokasi kelompok tani, sehingga disepakati akan diberikan bibitnya dari kampus FPIK Unpad. Selain itu disampaikan pula cara budidaya dan pemberian Lemna 
sp untuk ikan gurame, serta manfaat yang didapatkan dengan pemberian Lemna sp sebagai pakan ikan.

Pada kesempatan ini juga sekaligus dilakukan pemberian sertifikat uji kompetensi budidaya dari Dinas Perikanan dan Kelautan Ciamis pada 11 orang anggota kelompok yang telah lulus dalam ujian kompetensi.

\section{Kegiatan Monitoring dan Pendampingan}

Kegiatan monitoring dilakukan tiga minggu setelah pelaksanaan penyuluhan diberikan. Materi monitoring meliputi penanaman Lemna sp di kolam yang tersedia di kelompok tani dan cara pemeliharaan dan panennya. Peserta kegiatan diwakili oleh beberapa orang anggota kelompok dan penyuluh perikanan dari Desa Kertajaya Cijulang, yang berpartisipasi aktif dalam kegiatan tersebut. Adapun yang dievaluasi selama proses monitoring adalah proses penerabaran Lemna sp, pemberian pupuk, dan serta evaluasi pertumbuhan.

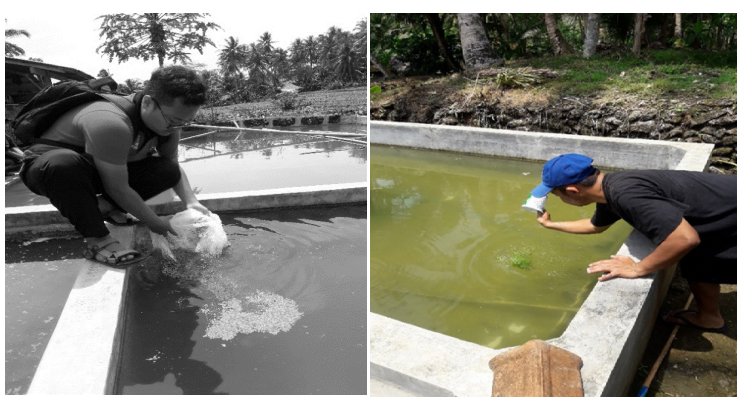

Gambar 3. Praktek Membudidayakan Lemna sp.

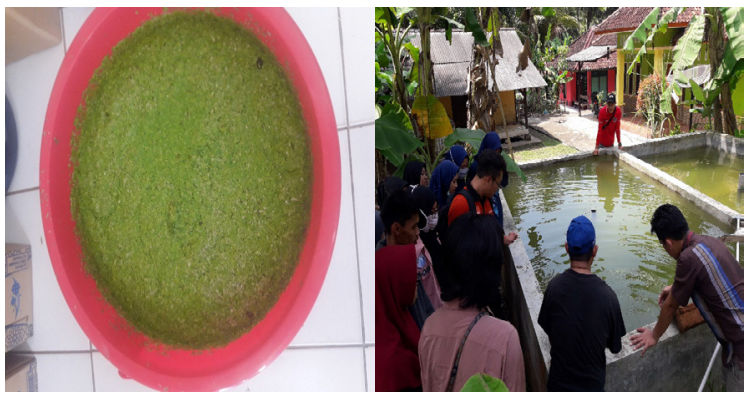

Gambar 4. Bibit Lemna sp dan Penyuluhan Cara Budidaya

Sambutan baik serta antusiasme dari Ketua Kelompok Pembudidaya Ikan Gurame Desa Kertayasa dalam menyambut kegiatan PPM Prioritas ini menjadi faktor terbesar yang mendorong terlaksananya kegiatan program PPM Prioritas ini. Selain itu, dukungan dan kerjasama yang diberikan oleh masyarakat setempat juga mempermudah kelancaran pelaksanaan program pemanfaatan Lemna sp sebagai pakan hijauan alternatif untuk budidaya gurame di Desa Kertayasa. Dukungan dan kerjasama yang diberikan oleh penyuluh Perikanan Dinas Perikanan dan Peternakan Pangandaran juga sangat membantu terlaksananya kegiatan PPM Prioritas ini dalam memberikan pendampingan dalam kegiatan.

Selain itu, terdapat juga hambatan dalam pelaksanaan PPM prioritas ini, diantaranya adalah sulitnya untuk menyepakati waktu pelaksanaan karena terbentur jadwal kegiatan atau pekerjaan kelompok serta terbenturnya kegiatan akademik yang padat sehingga kegiatan ini mengalami beberapa kali penjadwalan ulang. Namun pada akhirnya, disepakati bahwa kegiatan penyuluhan dilaksanakan pada hari Selasa tanggal 18-19 Juli 2017. Sasaran kegiatan pada penyuluhan ini yaitu kelompok pembudidaya ikan gurame. Sehingga pelaksanaan penyuluhan dapat dilaksanakan setelah kegiatan para pembudidaya selesai agar tidak mengganggu proses kegiatan rutinan kelompok tersebut. Pada waktu ini pun dianggap tepat karena pada waktu ini dapat dilakukan penyuluhan dan simulasi kegiatan cara budidaya Lemna sp.

\section{SIMPULAN}

Kegiatan pengabdian ini telah dilaksanakan dengan baik dan berjalan dengan lancar sesuai dengan rencana kegiatan yang telah disusun. Kegiatan ini mendapat sambutan baik dari aparat desa dan anggota kelompok tani yang terbukti turut mendukung kegiatan ini dengan aktif serta mengikuti petunjuk dari tim pendamping. Berdasarkan hasil kegiatan pengabdian kepada masyarakat ini maka dapat ditarik beberapa kesimpulan antara lain:

1. Pengetahuan dan pemahaman para petani tentang keunggulan nutrisi Lemna sp sebagai pakan hijauan untuk ikan gurame

3. Para pembudidaya juga memahami cara membudidayakan Lemna sp dan cara pemberiannya dalam pakan ikan gurame untuk meningkatkan pertumbuhan serta menambah volume panen ikan gurame.

\section{UCAPAN TERIMA KASIH}

Penulis mengucapkan terima kasih kepada Rektor Universitas Padjadjaran yang telah memberikan dana untuk kegiatan ini melalui Hibah Internal Pengabdian Kepada Masyarakat Universitas Padjadjaran berdasarkan kontrak No. 1364/UN6.3.1/PM/2017

\section{DAFTAR PUSTAKA}

Ilyas, A. P., K. Nirmala, E. Harris, dan T. Widiyanto. 2014. Pemanfaatan Lemna perpusilla Sebagai Pakan Kombinasi Untuk Ikan Nila (Oreochromis niloticus) Pada Sistem Resirkulasi. Jurnal Limnotek, 21: (2): 193-201.

Iqbal, S. 1999. Duckweed aquaculture potentials: Possibilities and limitations for combined wastewater treatment and animal feed production in developing countries. EAWAG, SANDEC Report No. 6/99. 
Landesman, L, N. C. Parker, C. B. Fedler, and M. Konikof. (2005). Modeling duckweed growth in wastewater treatment systems. Livestock Research for Rural Development. 17 (6) 2005.

Leng, RA, J. H. Stambolie and R. Bell. 1995. Duckweed - a potential high-protein feed resource for domestic animals and fish. Livestock Research for Rural Development, 7 (1).

Nekoubin, H. dan M. Sudagar. 2013. Effect of Different Types of Plants (Lemna sp., Azolla filiculoides and Alfalfa) and Artificial Diet (With Two Protein Levels) on Growth Performance, Survival Rate, Biochemical Parameters and Body Composition of Grass Carp (Ctenopharyngodon idella). Journal Aquaculture Research and Development, 4 (2): 6 hal.

Sulawesty, F., T. Chrismadha, dan E. Mulyana. 2014. Laju Pertumbuhan Ikan Mas (Cyprinus carpio L) Dengan Pemberian Pakan Lemna (Lemna perpusilla Torr.) Segar Pada Kolam Sistem Aliran Tertutup. Jurnal LIMNOTEK 201421 (2): 177 - 184. 